Article

\title{
The Impact of Purchasing Group on the Profitability of Companies Operating in the Renewable Energy Sector-The Case of Poland
}

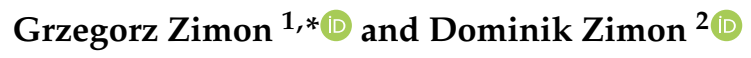 \\ 1 Department of Finance, Banking and Accountancy, The Faculty of Management, Rzeszow University of \\ Technology, 35-959 Rzeszow, Poland \\ 2 Department of Management Systems and Logistics, Rzeszow University of Technology, \\ 35-959 Rzeszow, Poland; zdomin@prz.edu.pl \\ * Correspondence: gzimon@prz.edu.pl; Tel.: +48-60-3979-034
}

Received: 13 November 2020; Accepted: 8 December 2020; Published: 14 December 2020

\begin{abstract}
Purchasing groups are multi-entity organisations that operate in practically every sector. Their greatest role is to improve the financial situation of small and medium enterprises (SMEs). In the case of enterprises operating in the sectors that are just developing, especially those belonging to SMEs, it is particularly difficult to obtain favourable financial results. In Poland, such sectors include, among others, renewable energy, which is slowly developing, but has not yet reached the size set in climate policy. The purpose of the paper is to present how functioning under group purchasing organisations (GPOs) affects the profitability of companies related to the renewable energy sector. For the example of the largest industry purchasing groups, the analysis showed that high profitability results were achieved by enterprises operating in them compared to entities operating independently in the market. In total, 71 enterprises operating in the sector related to the renewable energy sector in Poland were analysed. The enterprises were divided into units operating in the purchasing groups of 46 enterprises, and those that operate independently in the market of 25 enterprises. The research period covered the years 2016-2019. The analysis showed that the scale effect allowed companies to increase profits and had a positive effect on their financial liquidity. The research proved that in the case of commercial enterprises operating in the sector related to renewable energy, functioning within the industry purchasing group allowed high profitability and financial liquidity. There is a dependency that the liquidity increases with a growth in profitability.
\end{abstract}

Keywords: renewable energy; Polish energy; purchasing group; profitability

\section{Introduction}

Renewable energy sources (RES) are very popular, both on the global scale and in the European Union [1-5]. Renewable energy sources are developing dynamically in the countries of virtually all Europe. This is especially visible in the countries of Western and Southern Europe [6-9].

In Poland, the situation related to renewable energy is very complicated as coal poses a problem. This has been a symbol of the Polish energy sector.

The share of renewable sources in final energy consumption increased in Poland, but it is still low compared to other European Union countries.

Recently, as a result of protests by mining sector workers, it has been decided that the mines will not be closed until 2049. These are the arrangements of September 2020. Polish mines have been strongly supported by all Polish governments for many years. The vast majority of them are unprofitable, yet a wide stream of public funds is flowing to support mines. Today, the money transferred for Polish 
mines is not intended to increase the effectiveness of the operation of individual plants. Their task is to provide funds for salaries of mine workers who will continue extracting expensive coal, which has recently been purchased only by state-owned energy companies. In order to reduce the level of coal deposited by mines, the Polish government purchases this raw material itself through reserve agencies to improve the situation of the mining industry. Powerful state-owned energy companies such as PGE have to buy more expensive coal from Polish mines instead of importing it from abroad.

This results from protests by mining trade unions. Unfortunately, these policies will have a negative impact on the financial results of these companies, which should develop and rely as much as possible on renewable energy. Unfortunately, Polish mining and the activities of the Polish government are to some extent "a brake" for the development of renewable energy. In order to improve, they are heavily subsidized although in most cases they are unprofitable. On the other hand, miners are a social group strongly supported by the Polish government. What miners are unable to negotiate through talks and consultations with the government, they negotiate by protests and strikes, where they are often forced to present their physical strength in clashes with the police. An example of extraordinary support for the Polish mining industry is seen in the current situation where, as a result of the mine's closure due to a pandemic, mine employees receive salary payments of $100 \%$. All other industries in Poland receive a payment of $80 \%$. It is unclear why such discrepancies are introduced by the Polish government, but it is another proof of financing enterprises producing an unprofitable product. Certainly, these activities will not have a positive impact on their financial results. Until now, other state-owned companies related to the energy sector have often supported the mining sector financially, and it had a negative impact on their valuation in the market. A perfect example of such activities are the financial results of Polish energy companies and their current valuation. Statistical data from recent years show that the import of cheap coal to Poland is constantly growing. Figure 1 shows the detailed results.

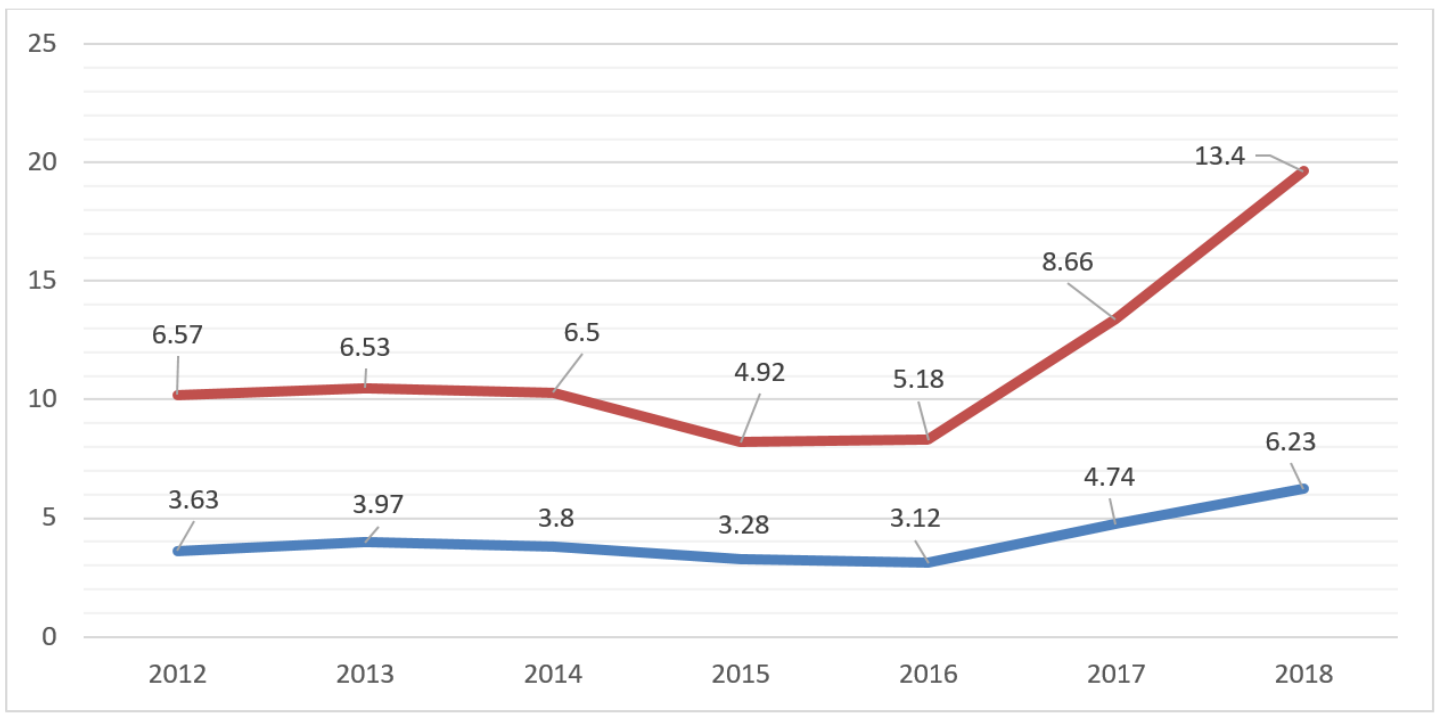

Figure 1. Hard coal import to Poland in the years 2012-2018 (in millions onnes). Source: Authors study based on Eurostat databases (Red: Import for Russia; Blue: Import from other destinations).

Figure 1 Import of hard coal to Poland in 2012-2018. Figure 1 shows how dynamically the level of coal import is growing. However, the goal of energy policy should be a gradual departure from this raw material. Figure 2 shows the targets for renewable energy and the results achieved by individual EU countries. 


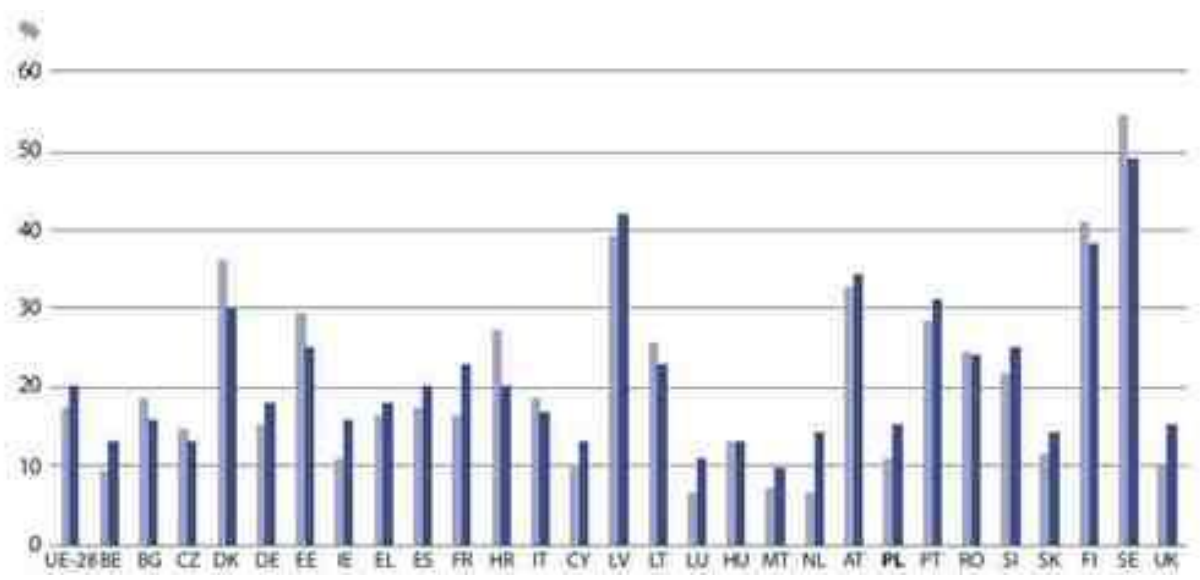

Figure 2. Share of energy from renewable sources, 2018. Source: Authors' study based on Eurostat databases.

Unfortunately, Poland is in the group of countries that did not achieve the intended goal, and it certainly will not.

\section{Literature Review}

\section{The Impact of Purchasing Groups}

A priority for Poland is to increase the share of renewable energy in the total structure. Government support is important in the perspective of development of renewable energy. Micro and small RES installations benefit from preferences-e.g., an easier connection to the grid, no need to obtain a license, exemption from commercial balancing costs. This aid is a great support for small business entities, but so far it has not brought such effects that would allow an implementation of previous assumptions concerning the share of renewable energy in the total structure. Figure 3 below shows the share of renewable energy in gross final energy consumption in Poland.

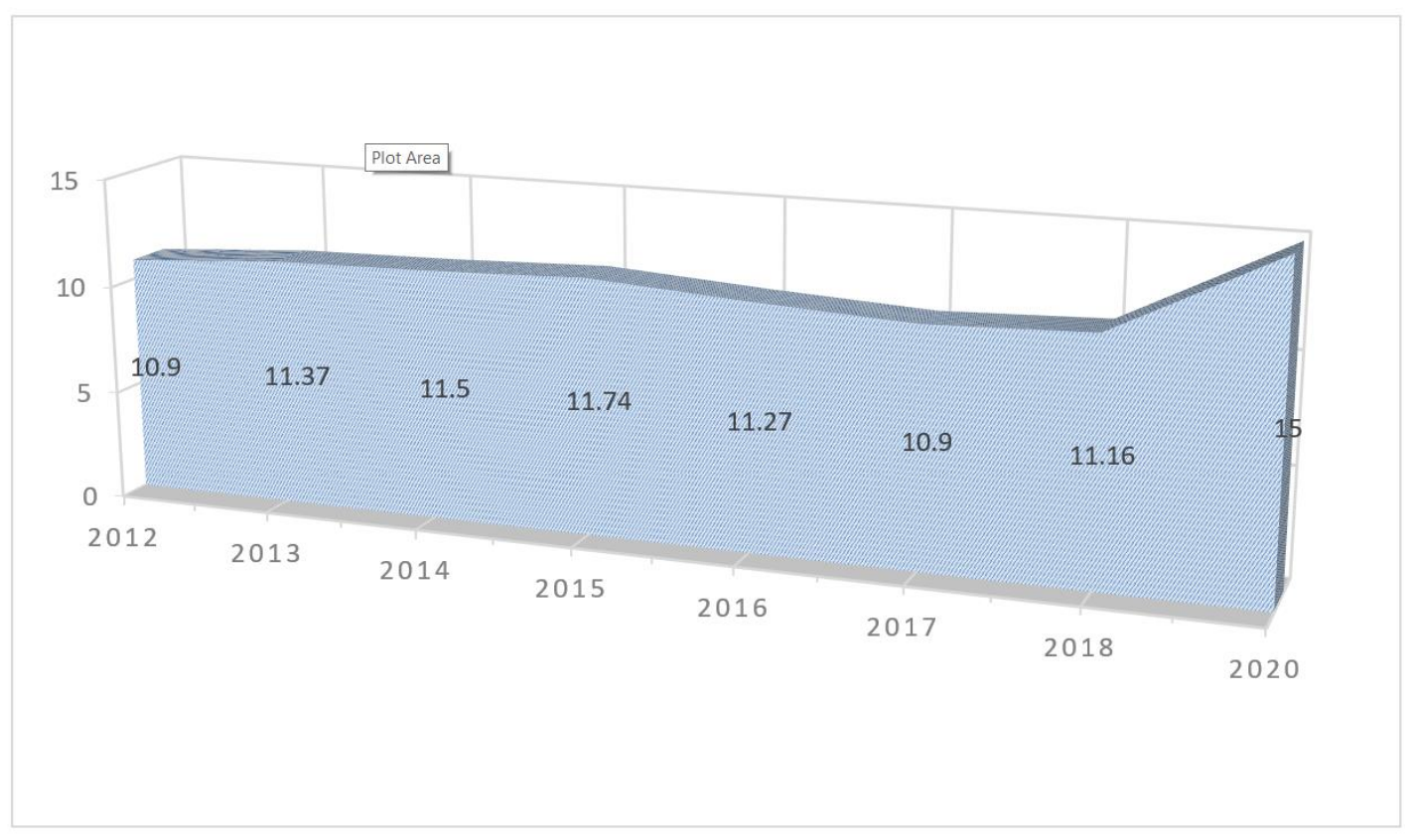

Figure 3. Share of energy from renewable sources in gross final energy consumption. Source: Authors' study based on Eurostat databases. 
The share of renewable energy in final energy consumption is growing, which should be assessed positively. Renewable energy in Poland is becoming "fashionable". However, when one compares this increase with the dynamics of coal consumption, it can be concluded that renewable energy is still at a low level. Statistical data clearly shows that solid biofuels, wind energy and liquid biofuels have the largest share in the structure of renewable energy. In 2018, the respective market share was $69.6 \%$, $12.40 \%$, and $10.3 \%$.

The direction based on the climate policy of the European Union clearly indicates that the sector related to renewable energy will develop dynamically, even in Poland. However, the units that will sell systems and all accessories related to renewable energy are needed. They are very often small and medium-sized enterprises which cannot base their trade $100 \%$ on equipment related to renewable energy. They have to compete with large chains of stores operating in the construction industry. In order to improve their situation in the market, these companies try to operate within purchasing groups. Their joint action is to provide enterprises with the means to survive in the market and, above all, to make a profit.

To be able to compete, retailers and their companies need to develop custom quotes to meet individual customer's needs, e.g., Cova \& Salle, (2008); Liinamaa et al., (2016); Panagopoulos, Rapp, \& Ogilvie, (2017); Tuli, Kohli and Bharadwaj, 2007 [10-12]. Working in groups gives such opportunities since it offers customers favourable prices and loans.

One recent study found that $60 \%$ of industrial buyers thoroughly researched a potential supplier, its products, and their competitors before contacting the seller [13-16]. Functioning in purchasing groups allows very effective use of benchmarking. By means of benchmarking and systematic exchange of information about recipients, especially those included in the group of unreliable ones, allows companies operating in purchasing groups to minimize the risk of concluding transactions with recipients who do not regulate them. The cooperation of companies within the purchasing group, and the development of benchmarking in various areas of the company operation, is undoubtedly an asset for entities operating in groups.

By analysing the literature and an evaluation of corporate financial management strategies, one can find a number of information and research which show that it is difficult for enterprises to achieve high financial liquidity and profits [17-21].

When analysing the research in the area related to the functioning of purchasing groups, one can find information that purchasing groups are organisations that may be able to maintain high financial liquidity and profits [22-24]. According to many authors, management of financial liquidity and profitability is closely related [25-34]. In general, managers have to decide whether to opt for a high-yield policy, or a policy that maintains high liquidity. When analysing the research on the area related to the functioning of purchasing groups, one can find information that purchasing groups are organisations that may be able to maintain high financial liquidity and profits [35-37]. The literature lacks studies on group purchasing organisations in combination with profitability and liquidity management strategies. In general, the authors state that they affect the costs and prices of purchased goods, materials or finished products. There are also no studies on SMEs operating in such groups. In recent years, more and more studies have appeared where the authors try to assess the impact of purchasing groups on financial results and financial security. It should be remembered that, when analysing the functioning of units in terms of financial liquidity management, it is always worth looking at the profitability results and the assessment of the relationship between profitability and financial liquidity. In the paper the authors try to assess the influence of purchasing groups on profitability and assess whether there is a statistically significant relationship between profitability and liquidity.

Purchasing groups are multi-entity organisations whose primary goal is to make joint purchases. Today they are created in virtually every industry [38-45].

Their greatest benefit is the economies of scale and purchasing power, which in the case of commercial enterprises, reduce costs $[37,39,45-52]$. 
These discounts are widespread, and are often the impetus for consumers to form buying groups, or group purchasing organisations [36].

Several papers have suggested that GPOs are a way for buyers to a mass bargaining power $[53,54]$.

Dana (2003) shows that when buyers form groups that commit to buy exclusively from one supplier, they obtain a lower price equal to their supplier's marginal cost [55-61].

It also improves financial liquidity and the efficiency of asset management. The research conducted so far has shown that quality management systems also have a positive effect on the financial results of GPOs [17,62]. Most often, SMEs operate in purchasing groups as functioning within the group, in addition to improving financial results. This allows them to obtain high financial liquidity, which in turn enables companies to build a strong competitive position in the market. Moreover, within purchasing groups enterprises establishing cooperation, mutual transactions that may improve the financial situation of enterprises appear. Thanks to such transactions, an enterprise or the central unit of the purchasing group can extend the trade credit or quickly repay the amount due to the company that is in financial trouble, or simply borrow funds.

Figure 4 shows a model of operation of an industry purchasing group operating in the sector related to the renewable energy industry.

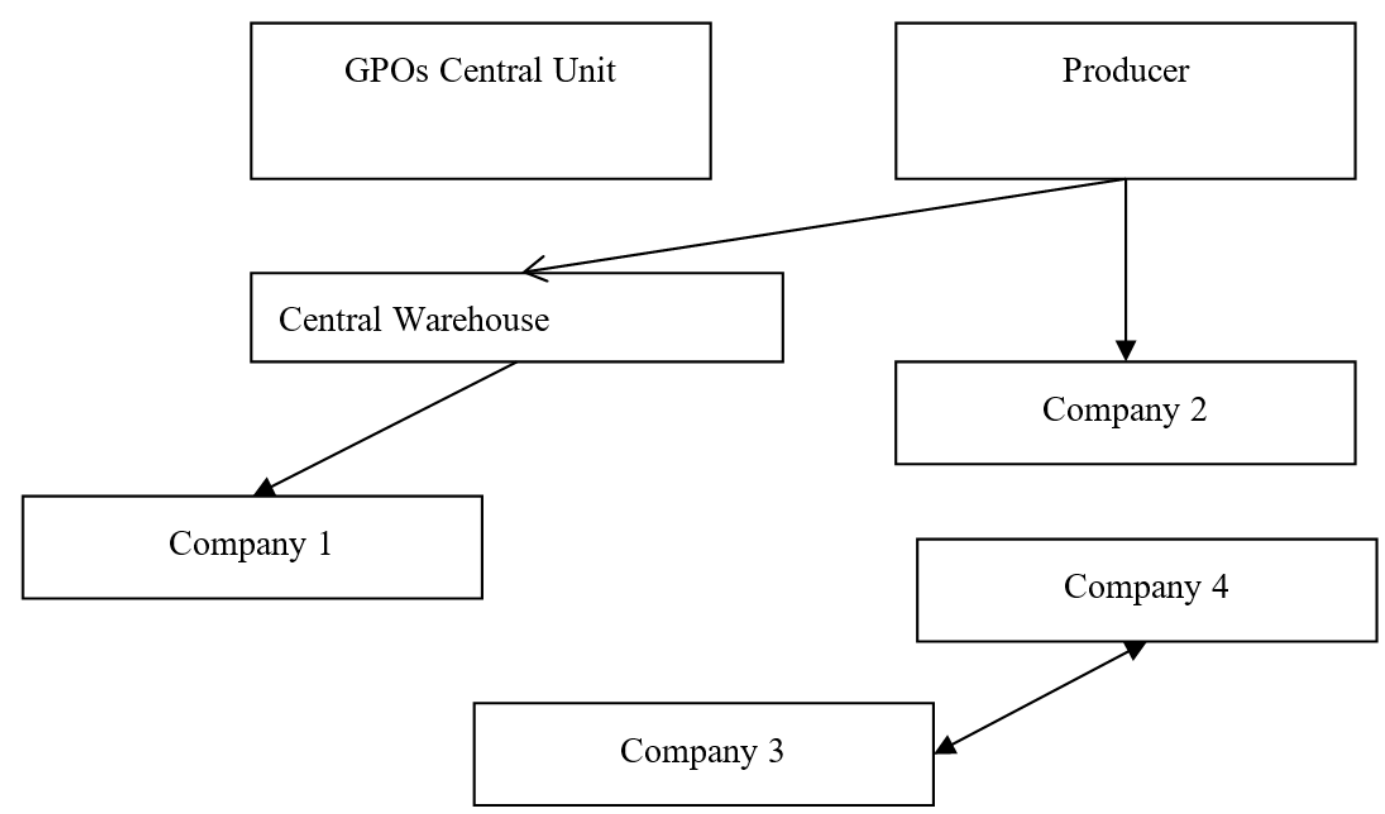

Figure 4. Model of operation of an industry purchasing group operating in the sector related to the renewable energy.

Industry purchasing groups consist of the central unit with the central warehouse and companies making up the group. The central warehouse plays an important role in such groups, while the central warehouse increases the possibilities of deliveries within the purchasing group. This allows an increase in the purchasing power of such a purchasing group, which improves the level of sales and profitability. The central unit can purchase goods from its own resources, which are delivered to the central warehouse, and sold to enterprises with a small margin if needed. Such activities allow the central unit to earn funds, which reduces the need for additional funds from participants in the purchasing group.

So far, the research on purchasing groups has provided general information that acting together allows a company to obtain high profitability and liquidity compared to entities operating independently [35].

The purpose of the paper is to present in detail how the functioning of GPOs affects the profitability of enterprises. 


\section{Data and Methods}

The analysis covers 71 companies, 46 of which operated in the purchasing group, and 25 were independent entities. The main goal of the analysis is to compare selected financial ratios between the two groups. The table presents the values of descriptive statistics (mean, median, standard deviation, as well as minimum and maximum) for selected financial indicators related to the profitability of enterprises in two groups.

The significance of differences between the two groups of enterprises in the ROS distribution was assessed using the Mann-Whitney test. Test was used to assess the significance of differences in the level of selected financial indicators in groups. The authors choice of the non-parametric test was dictated by the lack of normality of the distribution of financial indicators in the groups.

One of the goals of the statistical analysis was to examine the relationships between the selected financial ratios. For this purpose, the correlation analysis and the linear regression model were used. The form of the regression model (selection of the dependent variable and independent variables) resulted from the research problems posed in the paper.

The purpose of the paper is to show:

- why operating within purchasing groups allows companies to obtain high profits,

- whether there is a relationship between financial liquidity and profitability,

- how the operation of the industry purchasing group model in the renewable energy sector allows cost optimization.

The paper attempts to verify the following Hypothesis:

Hypothesis 1. It is assumed that in the case of companies operating within purchasing groups in the renewable energy sector, the level of financial liquidity increases with the growth in profitability.

As for the selection of companies for the analysis, it was limited by the availability of data. The largest industry purchasing groups in Poland were tested. In the case of entities operating in the renewable energy sources industry, 46 out of 71 companies were analysed. In the case of independent units, 82 enterprises were selected. Financial data was obtained from 25 units.

When analysing the data, it was assumed that companies that did not disclose their data did not differ significantly in terms of financial results from the companies from which the data was obtained. In fact, this assumption underlies all partial statistical surveys in which there was a "refusal to respond" in some cases.

\section{Results}

The first stage of the analysis was to compare the sales profitability results for both groups of enterprises. Table 1 below presents profitability ratios for the enterprises analysed.

Table 1. Profitability ratios for the enterprises analysed (2016-2019).

\begin{tabular}{|c|c|c|c|c|c|c|c|c|c|c|c|}
\hline \multirow{3}{*}{$\begin{array}{l}\text { Financial } \\
\text { Indicators }\end{array}$} & \multicolumn{10}{|c|}{ Group } & \multirow{3}{*}{$p$} \\
\hline & \multicolumn{5}{|c|}{ GPO $(N=46)$} & \multicolumn{5}{|c|}{ Independent Enterprises $(N=25)$} & \\
\hline & Mean & Me & $\begin{array}{l}\text { Std. } \\
\text { Dev. }\end{array}$ & Min & Max & Mean & $\mathrm{Me}$ & $\begin{array}{l}\text { Std. } \\
\text { Dev. }\end{array}$ & Min & $\operatorname{Max}$ & \\
\hline $\begin{array}{l}\text { ROS (return on } \\
\text { sales) [\%] }\end{array}$ & 4.52 & 4.21 & 2.92 & 1.08 & 14.05 & 2.01 & 1.16 & 0.91 & 0.99 & 8.20 & $0.0000^{* * *}$ \\
\hline
\end{tabular}

The differences between the two groups are clearly visible. Higher profitability ratios are achieved by units operating within purchasing groups. The next stage of the research was to evaluate the 
influence of purchasing groups on the profitability of enterprises. For this purpose, the greatest benefits obtained by enterprises operating in groups were presented. Then they were related to the appropriate assets and liabilities that had the significant impact on the level of profitability and financial liquidity, i.e., short-term receivables, short-term liabilities, inventories and the operating cycle.

In the case of the purchasing groups, the greatest benefits they obtained through the economies of scale concerned:

- reduction of costs in the item value of materials, goods at purchase price,

- attractive trade credit and the possibility of creating a competitive policy of managing receivables from customers. By obtaining a long period of payment of obligations towards the producer (the funds are paid into the account of the central unit), it is possible to extend the trade credits to the recipients. Today, when the prices of services and goods are at a similar level, an attractive trade loan allows retaining existing customers and gaining new ones,

- the use of additional discounts for early payment of liabilities. Very often companies receive an additional discount for a quick, early payment. This discount is particularly important for the company financial results and financial liquidity. It allows one to further reduce costs in the item value of goods sold at purchase price, which increases profits which, in the form of financial resources, improve financial liquidity.

In a similar way, using a regression model, the existence and specificity of possible relationships between the cycles of receivables, liabilities and inventories, as well as belonging to GPO and the profitability ratio will be examined.

The dependent variable of the regression model was profitability, and the independent variables: The length of the receivables, liabilities and inventories cycles and the dichotomous factor-Affiliation to the GPO. Additionally, interactions between membership in the GPO and the length of receivables, liabilities and inventories cycles were taken into account.

The model explains quite well the variability of ROS among the surveyed companies $\left(R^{2}=64.9 \%\right)$. The most important conclusions can be summarized in the following points:

- when controlling the length of financial cycles, no statistically significant difference has been found in the level of profitability of companies with GPO and independent companies $(p=0.1918)$-This means that if you compare companies with GPO and independent companies with a similar length of financial cycles, they also have a similar profitability;

- extending the inventory cycle by one day results, on average, in reducing profitability by 0.033 (ppt) - This impact is statistically significant $\left(p=0.0338^{*}\right)$ and occurs regardless of the company's affiliation to GPOs (insignificant interaction group $\times$ inventory turnover ratio);

- the length of receivables cycles is statistically significant only in interaction with the company's affiliation to GPO $(p=0.0291 *)$-Among companies with GPO, along with an increase in the length of receivables cycles by one day, ROS increases (on average by $0.038 \mathrm{ppt}$, and among independent companies, the increase receivables cycle causes a decrease in ROS (on average by $0.052 \mathrm{ppt}$;

- it is similar for the length of the liability cycle $\left(p=0.0076^{* *}\right)$, but here in the group of companies with GPO, one can observe a decrease in ROS along with the extension of the liability cycle (by 0.042 ppt per one day of the cycle extension of liabilities), and among stand-alone companies an increase in ROS (on average by $0.024 \mathrm{ppt}$ ).

Companies within GPOs, thanks to the scale of purchases, obtain favourable trade credit. This allows them to gain new contractors through the offer of an attractive trade loan. This policy increases the turnover of receivables from customers within days, however, it translates into an increase in sales and sales profitability. As confirmed by the results in Table 2. The GPO commitment management policy consists of three stages at which the companies operating in GPO receive additional benefits. The most important element of this policy is the possibility of obtaining an additional discount 
for an early payment. The scale effect allows the purchasing group's central unit to negotiate with producers. The result of these negotiations is an attractive price and a trade credit. The length of the trade credit is the first important information received by companies operating in GPOs. The extended maturity of the trade credit has a large impact on the profitability of enterprises, as they obtain the cheapest source of financing their activities, which are liabilities to suppliers. Importantly, it is the so-called non-interest source of financing because very often in the case of late payment the recipient does not charge penalty interest, especially to regular partners. Thus, the enterprise, thanks to the long-term trade loan, does not have to finance its operations with an expensive bank loan. The long-term payment of liabilities to suppliers makes the receivables management policy with regard to trade credits more attractive, which should attract new contractors who will increase the sales level and margin.

Table 2. Results for regression model with ROS as a dependent variable.

\begin{tabular}{cccc}
\hline \multirow{2}{*}{ Effects } & \multicolumn{3}{c}{ ROS (Return on Sales) [\%] } \\
& \multicolumn{1}{c}{$\boldsymbol{R}^{\mathbf{2}=\mathbf{6 4 . 9} \%} \mathbf{F = \mathbf { 1 4 . 9 }} \boldsymbol{p = \mathbf { 0 . 0 0 0 0 }}{ }^{* * *}$} \\
\cline { 2 - 4 } & $\boldsymbol{B}$ & $\boldsymbol{p}$ & $\boldsymbol{\beta}$ \\
\hline Group (GPO vs. independent) & $1.938 \%$ & 0.1918 & 0.757 \\
Receivables turnover ratio & $0.008 \%$ & 0.7443 & 0.058 \\
Liabilities turnover ratio & $-0.009 \%$ & 0.4377 & -0.126 \\
Inventory turnover ratio & $-0.033 \%$ & $0.0338^{*}$ & -0.254 \\
Group $\times$ receivables turnover ratio & $0.045 \%$ & $0.0291^{*}$ & 1.361 \\
Group $\times$ liabilities turnover ratio & $-0.033 \%$ & $0.0076^{* *}$ & -1.177 \\
Group $\times$ inventory turnover ratio & $-0.016 \%$ & 0.2867 & -0.508 \\
\hline
\end{tabular}

$B$-regression coefficient, $p$-assessment of statistical significance. $\beta$-standardized regression coefficient. $* * * *$, and *** denotes statistical significance of effects or whole model (respectively at level $p<0.05 ; p<0.01$ and $p<0.001$ ). Source: author's calculations and studies.

The second benefit resulting from an efficient policy of managing liabilities in purchasing groups is an additional discount for an early payment. In the case of GPO, if there is an additional discount, it is basically always used. If such a possibility arises, the central unit makes advance payment, which translates into a low price of the goods purchased. The use of discounts has a very large impact on the increase in the profitability level. However, it results in shortening the deadlines for paying liabilities and a decrease in their share in financing the entity. The fast rotation of liabilities in days for the environment is a clear signal that this company has no financial problems. It is a sign for the environment that it is worth cooperating and trading with such an enterprise. The decrease in the level of liabilities negatively affects the real financial liquidity, as short-term liabilities decrease in liabilities and cash in hand in current assets. Thus, most liquid assets are lost. The last benefit resulting from the impact of GPO on liabilities is an additional bonus. It is a reward for completing the appropriate level of purchase of goods, materials or products. It depends on the turnover and has a large impact on the level of the company's operating costs. This premium means an even lower price for subsequent purchased goods, materials that will be reduced with subsequent deliveries. There may also be corrections to previous invoices, which lower the prices of purchased products and materials. This premium also has a big impact on profitability.

The possibility of obtaining the presented benefits leads to a low rotation of liabilities towards suppliers in days compared to independent companies, which is presented in Table 3 The analysis was also enriched with a comparison of the rotation of liabilities towards suppliers.

The analysis was enriched with a comparison of the average results regarding the indicators of liabilities towards suppliers in days.

The results presented in Table 3 clearly indicate that companies operating in GPOs intentionally pursue a policy aimed at quick payment of liabilities in order to obtain additional loans and bonuses for early payment of liabilities. 
The relationship between liquidity and efficiency (on the one hand) and profitability (on the other hand) were investigated using the linear correlation coefficient. The analysis was conducted separately for companies with GPO and independent companies. The results for the entire group are also given. The detailed results are shown in Table 4 .

Table 3. Rotation of liabilities to suppliers for the enterprises analysed (2016-2019).

\begin{tabular}{|c|c|c|c|c|c|c|c|c|c|c|c|}
\hline \multirow{3}{*}{$\begin{array}{c}\text { Rotation of } \\
\text { Liabilities } \\
\text { Towards } \\
\text { Suppliers in } \\
\text { Days }\end{array}$} & \multicolumn{10}{|c|}{ Group } & \multirow{3}{*}{$p$} \\
\hline & \multicolumn{5}{|c|}{$\begin{array}{c}\text { GPO } \\
(N=46)\end{array}$} & \multicolumn{5}{|c|}{$\begin{array}{l}\text { Independent Enterprises } \\
\qquad(N=25)\end{array}$} & \\
\hline & Mean & Me & $\begin{array}{l}\text { Std. } \\
\text { Dev. }\end{array}$ & Min & Max & Mean & Me & $\begin{array}{l}\text { Std. } \\
\text { Dev. }\end{array}$ & Min & Max & \\
\hline $\begin{array}{c}\text { Rotation of } \\
\text { Liabilities } \\
\text { Towards } \\
\text { Suppliers in } \\
\text { Days }\end{array}$ & 60.4 & 57.1 & 25.8 & 41.4 & 117.06 & 103.2 & 110.7 & 33.2 & 34.5 & 120.3 & 0.0000 ** \\
\hline
\end{tabular}

Table 4. An analysis of the relationship between liquidity, efficiency and profitability in the surveyed enterprises.

\begin{tabular}{cccc}
\hline \multirow{2}{*}{ Financial Indexes } & \multicolumn{3}{c}{ Group } \\
\cline { 2 - 4 } & GPO & Independent Enterprises & Total \\
\cline { 2 - 4 } & \multicolumn{3}{c}{ ROS (Return on Sales) [\%] } \\
\hline Operating cycle [days] & $0.04(p=0,7840)$ & $-0.16(p=0.4780)$ & $-0.11(p=0.3711)$ \\
\hline Current financial liquidity ratio & $0.45\left(p=0.0033^{* *}\right)$ & $-0.27(p=0.2209)$ & $0.56\left(p=0.0000^{* * *}\right)$ \\
\hline $\begin{array}{c}p \text { value was calculated using the Mann-Whitney test. }{ }^{* *} \text { and } \\
\text { groups (respectively at level } p<0.05 ; p<0.01 \text { and } p<0.001) ; \text { Source: author's calculations and studies. }\end{array}$
\end{tabular}

There was no statistically significant relationship in any group between the operating cycle and profitability. The relationship was found between the profitability of sales and financial liquidity. The results of the analyses are illustrated in the scatter charts Figure 5.
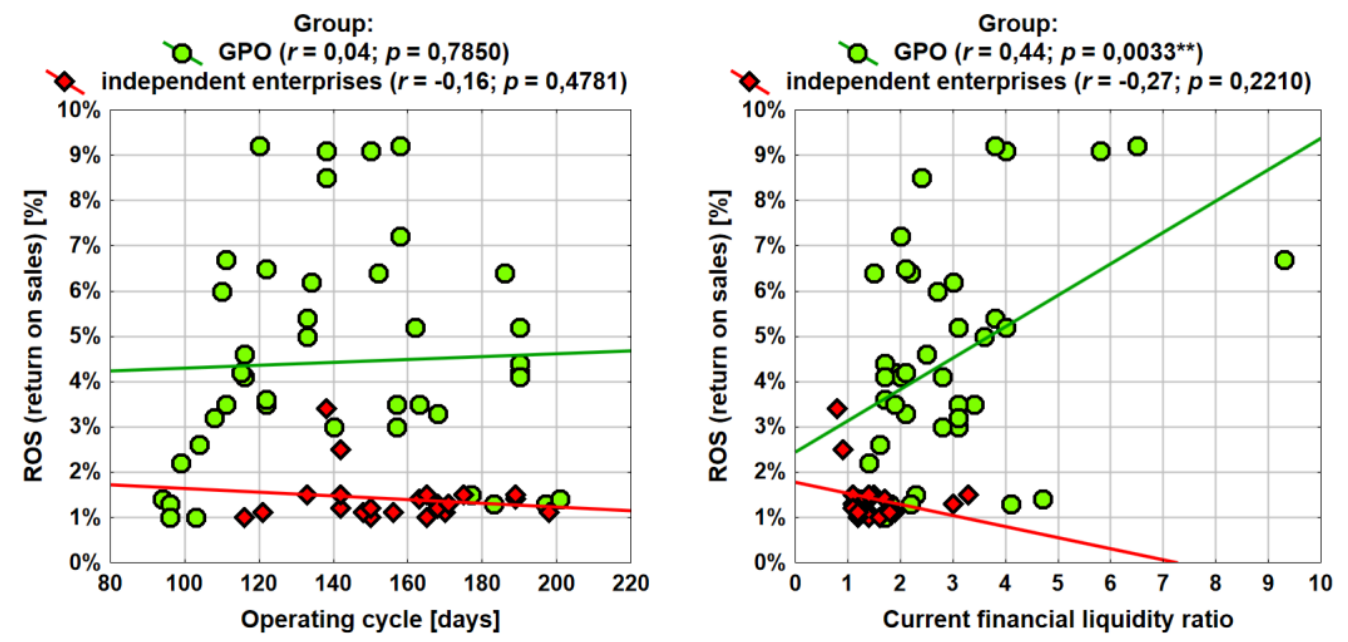

Figure 5. An analysis of the relationship between the operating cycle and profitability. 
The analysis was enriched with a comparison of average results regarding sales revenues, operating costs and ratios of liabilities to suppliers on days. The details are presented in Table 5.

Table 5. Net revenues from sales and operating expenses for the analysed enterprises (2016-2019).

\begin{tabular}{|c|c|c|c|c|c|c|c|c|c|c|c|}
\hline \multirow{3}{*}{$\begin{array}{c}\text { Financial } \\
\text { Variables } \\
\text { [mln PLN] }\end{array}$} & \multicolumn{10}{|c|}{ Group } & \multirow{3}{*}{$p$} \\
\hline & \multicolumn{5}{|c|}{$\begin{array}{c}\text { GPO } \\
(N=46)\end{array}$} & \multicolumn{5}{|c|}{$\begin{array}{l}\text { Independent Enterprises } \\
\qquad(N=25)\end{array}$} & \\
\hline & Mean & Me & $\begin{array}{l}\text { Std. } \\
\text { Dev. }\end{array}$ & Min & Max & Mean & Me & $\begin{array}{l}\text { Std. } \\
\text { Dev. }\end{array}$ & Min & Max & \\
\hline $\begin{array}{l}\text { Net revenues } \\
\text { from sales }\end{array}$ & 57.0 & 32.7 & 64.5 & 5.3 & 331.8 & 18.9 & 12.9 & 28.4 & 2.2 & 148.7 & $0.0000^{* * *}$ \\
\hline $\begin{array}{l}\text { Operating } \\
\text { expenses }\end{array}$ & 52.4 & 26.9 & 61.7 & 5.1 & 313.3 & 17.4 & 11.7 & 27.0 & 1.3 & 140.3 & $0.0001^{* * *}$ \\
\hline
\end{tabular}

$p$ value was calculated using the Mann-Whitney test. ${ }^{* * *}$ denotes statistical significance of difference between groups (respectively at level $p<0.05 ; p<0.01$ and $p<0.001$ ); Source: author's calculations and studies.

Enterprises operating in GPOs have a significantly higher level of costs and revenues ( $p$ value for both comparisons is below 0.001). The distribution of both compared financial values is characterized by right-hand asymmetry (both in GPOs and in independent companies), which can be seen on the basis of the comparison of means and medians. Therefore, the median is a better measure of the average level of costs and revenues.

While analysing the results concerning the volume of sales revenues and costs, statistically significant differences were observed in the averages calculated for both groups of enterprises. The units operating in GPOs achieve a much higher level of sales revenues and operating costs. The higher the sales revenues, the stronger the position of the central unit in negotiations with contractors. High sales revenues mean high margins and profits. This is confirmed by the results concerning the profitability of sales presented in Table 1. It is also worth noting in the case of purchasing groups a significantly higher difference between the results of the average for sales revenues and operating costs compared to entities operating independently on the market.

In the case of purchasing groups, an increase in turnover means an increase in profitability.

\section{Discussion and Conclusions}

There are many studies in the literature where the authors argue that profitability cannot improve with increasing liquidity [22-27,35]. In general, companies are either highly liquid or profitable. It is difficult to find a strategy that would achieve high profitability and liquidity. Purchasing groups allow reducing costs, and cooperation and trust enable companies to operate within the purchasing group to improve safety.

The analysis showed that in GPOs there is a statistically significant relationship $\left(p=0.0033{ }^{* *}\right)$ with average strength $(r=0.45)$ between financial liquidity and profitability. Higher financial liquidity is a factor contributing to higher profitability-Although, as already mentioned, it is not a strong relationship.

Such a relationship is undoubtedly a novelty in the field of research on financial liquidity and profitability. It is particularly important for industries that are developing in the market. It allows building financial security, and at the same time generating profits, which will certainly build a strong competitive position in the market in the future. Based on the previous results (Table 2) and the following research implication, it can be stated that the Hypothesis 1 is confirmed. The research has shown that in the case of commercial enterprises operating in the sector related to renewable energy, functioning within the industry GPO allows high profitability and financial liquidity. There is a dependency that the liquidity increases with the growth in profitability. Until now, the authors in their research indicated that liquidity in units as profitability increases or vice versa. 
This is due to the specificity of industry purchasing groups. Industry purchasing groups take advantage of the economies of scale, which significantly reduces costs. In addition, the introduction of the central warehouse in GPO allows obtaining benefits not only for the central unit, but also for all participants of a given group. The central warehouse allows companies operating in GPO to place an order quickly and replenish the missing range at a better price compared to the prices offered by producers. Stock replenishment from the GPP warehouse has a positive effect on profitability.

This is confirmed by the profitability results of the enterprises analysed, where significantly higher results are obtained by enterprises operating in industry purchasing groups.

Working together in GPOs also means getting beneficial trade credits that allow one to take advantage of additional discounts. The discounts obtained mean an increase in cash, which allows improving financial security. The cooperation enables participants of purchasing groups to use the finances of a central unit or another company in the event of problems. These transactions can be referred to as mutual transactions.

One cannot disagree with the authors who claim that the financial security of GPOs is based on trust within the group $[27,55,57]$. Only cooperating companies within the group can improve their financial results and optimize the level of financial liquidity.

In the case of enterprises operating in the sector related to renewable energy, which is only just developing in Poland, functioning in industry purchasing groups seems to be the optimal solution. The energy industry is an industry for specific customers in Poland closely related to the construction industry, in which many bankruptcies have been observed in recent years. Therefore, it is very risky to rely on this group of contractors and GPOs provide a certain security for the continuity of the functioning of enterprises that trade in Poland in equipment related to the renewable energy sector.

\subsection{Finding and Implications}

The results of research confirm that accession to the purchasing group translates into better financial performance of the organizations. This is due to the fact that a purchasing group usually provides additional power to the members of the group in their negotiations with suppliers. Consequently, members should get more favourable conditions than those they would have obtained individually [58]. However, a purchasing group also constitutes an additional link in the supply chain and its objectives could go contrary to those of some of its members [63-66]. This is why organisations considering joining a purchasing group should analyse this option strategically, in order to correctly assess the potential long-term benefits [42]. Therefore, when joining a purchasing group, organizations should be aware that, on the one hand, they receive benefits in the form of economies of scale, on the other hand, they may lose some of their sovereignty. Due to the very limited number of articles on the topic under study, it can be concluded that the findings of the study have a range of implications for managers, who will be able to more consciously make decisions about switching to a purchasing group and predict more accurately what profits they can gain from it.

\subsection{Limitations and Future Research}

This study's limitations include the country context in which our data was solicited, the size of our sample, and the industry context. To this end, the results are not generalizable globally but are valid and reliable for future studies and continuation of this field of research. Another limiting factor may be the methodological side of research. As for the selection of companies for the analysis it was limited by the availability of data. When analysing the data, it was assumed that the companies that did not disclose their data (the authors asked all GPOs companies for them) do not differ significantly in terms of financial results from the companies from which the data was obtained. According to the authors, the sizes of the compared groups are not very small (46 and 25 cases), in statistics, groups of at least 30 cases are conventionally considered "large", so here we are very close to this condition. The authors are aware that increasing the sample size would have a positive effect on the value of work. Always, the fuller the data, the better. On the other hand, the results of statistical tests—as we know-depend 
on the sample size in such a way that the smaller the size of the compared groups, the more difficult it is to obtain statistically significant differences. The small size of the groups (except for really extreme cases) does not affect the reliability of the statistical test results. Therefore, undertaking the analysis of small groups is really risky on the part of the researcher, while the fact of obtaining statistically significant differences and relationships for a small sample is somewhat more valuable than for large samples. The authors are also aware that some of the differences between GPOs and stand-alone companies may be apparent. However, during the statistical analysis of the data held, no results appeared that would indicate this in any way.

Despite these limitations, however, the presented research offers a relatively new perspective on the quantitative analysis of GPO. It can serve as one of the starting points for a more in-depth analysis of the financial situation in purchasing groups. The authors hope that the research directions initiated in the article will be continued. It seems particularly important to compare the obtained results with organizations forming purchasing groups in Western Europe and other industries.

Author Contributions: Conceptualization, G.Z; methodology, G.Z; formal analysis, G.Z; data curation, G.Z; writing-original draft preparation, G.Z; writing—review and editing, G.Z, D.Z.; visualization, G.Z; supervision, G.Z.; project administration, G.Z; funding acquisition, G.Z. All authors have read and agreed to the published version of the manuscript.

Funding: This research received no external funding.

Conflicts of Interest: The authors declare no conflict of interest.

\section{References}

1. Cucchiella, F.; D'Adamo, I.; Gastaldi, M. Future Trajectories of Renewable Energy Consumption in the European Union. Resources 2018, 7, 10. [CrossRef]

2. Palma, H.H.; Ibarra, K.H. evaluation of photovoltaic energy projects using the real options valuation. Int. J. Energy Econ. Policy 2020, 10, 256-265. [CrossRef]

3. Irtija, N.; Sangoleye, F.; Tsiropoulou, E.E. Contract-Theoretic Demand Response Management in Smart Grid Systems. IEEE Access 2020, 8, 184976-184987. [CrossRef]

4. King, C.W.; Hall, C.A.S. Relating Financial and Energy Return on Investment. Sustainability 2011, 3, 1810-1832. [CrossRef]

5. Kath, C.; Nitka, W.; Serafin, T.; Weron, T.; Zaleski, P.; Weron, R. Balancing Generation from Renewable Energy Sources: Profitability of an Energy Trader. Energies 2020, 13, 205. [CrossRef]

6. Del Río, P.; Peñasco, C.; Mir-Artigues, P. An overview of drivers and barriers to concentrated solar power in the European Union. Renew. Sustain. Energy Rev. 2018, 81, 1019-1029. [CrossRef]

7. Abdeltawab, H.M.; Mohamed, Y.A.I.; Abdeltawab, H.M.; Mohamed, Y.A.I. Distributed Battery Energy Storage Co-Operation for Renewable Energy Sources Integration. Energies 2020, 13, 5517. [CrossRef]

8. Meijer, L.; Huijben, J.; Van Boxstael, A.; Romme, G. Barriers and drivers for technology commercialization by SMEs in the Dutch sustainable energy sector. Renew. Sustain. Energy Rev. 2019, 112, 114-126. [CrossRef]

9. Foxon, T.; Gross, R.; Chase, A.; Howes, J.; Arnall, A.; Anderson, D. UK innovation systems for new and renewable energy technologies: Drivers, barriers and systems failures. Energy Policy 2005, 33, $2123-2137$. [CrossRef]

10. Panagopoulos, N.G.; Rapp, A.A.; Ogilvie, J.L. Salesperson Solution Involvement and Sales Performance: The Contingent Role of Supplier Firm and Customer-Supplier Relationship Characteristics. J. Mark. 2017, 81, 144-164. [CrossRef]

11. Cova, B.; Salle, R. Marketing solutions in accordance with the S-D logic: Co-creating value with customer network actors. Ind. Mark. Manag. 2008, 37, 270-277. [CrossRef]

12. Liinamaa, J.; Viljanen, M.; Hurmerinta, A.; Ivanova-Gongne, M.; Luotola, H.; Gustafsson, M. Performance-based and functional contracting in value-based solution selling. Ind. Market. Manag. 2016, 59, 37-49. [CrossRef]

13. Tuli, K.R.; Kohli, A.K.; Bharadwaj, S.G. Rethinking Customer Solutions: From Product Bundles to Relational Processes. J. Market. 2007, 71, 1-17. [CrossRef] 
14. Sarkar, B.; Omair, M.; Kim, N. A cooperative advertising collaboration policy in supply chain management under uncertain conditions. Appl. Soft Comput. 2020, 88. [CrossRef]

15. Steward, M.D.; Narus, J.A.; Roehm, M.L.; Ritz, W. From transactions to journeys and beyond: The evolution of B2B buying process modeling. Ind. Mark. Manag. 2019, 83, 288-300. [CrossRef]

16. Müller, J.M.; Pommeranz, B.; Weisser, J.; Voigt, K.-I. Digital, Social Media, and Mobile Marketing in industrial buying: Still in need of customer segmentation? Empirical evidence from Poland and Germany. Ind. Mark. Manag. 2018, 73, 70-83. [CrossRef]

17. Zimon, D.; Zimon, G. The impact of implementation of standardized quality management systems on management of liabilities in group purchasing organisations. Qual. Inno. Prosper. 2018, 23, 60-73. [CrossRef]

18. Hendershott, T.; Jones, C.M.; Menkveld, A.J. Does algorithmic trading improve liquidity? J. Financ. 2011, 66, 1-33. [CrossRef]

19. Kontuš, E.; Mihanovi'c, D. Management of liquidity and liquid assets in small and medium-sized enterprises. Econ. Res. Ekon. Istraž. 2019, 32, 3247-3265. [CrossRef]

20. Degryse, H.; Matthews, K.; Zhaoca, T. SMEs and access to bank credit: Evidence on the regional propagation of the financial crisis in the UK. J. Financ. Stab. 2018, 38, 53-70. [CrossRef]

21. Wójcik-Jurkiewicz, M.; Sadowska, B. Non-financial reporting standards and evaluation of their use illustrated with example of Polish listed companies. Eur. J. Serv. Manag. 2018, 27, 539-545. [CrossRef]

22. Martínez-Sola, C.; García-Teruel, P.J.; Martínez-Solano, P. Trade credit and SME profitability. Small Bus. Econ. 2013, 42, 561-577. [CrossRef]

23. Bougheas, S.; Mateut, S.; Mizen, P. Corporate trade credit and inventories: New evidence of a trade-off from accounts payable and receivable. J. Bank. Financ. 2009, 33, 300-307. [CrossRef]

24. Sadowska, B. The Importance of Environmental-forest Education in Managing Information on Natural Resources. WSEAS Trans. Bus. Econ. 2020, 17, 775-785. [CrossRef]

25. DeLoof, M. Does Working Capital Management Affect Profitability of Belgian Firms? J. Bus. Financ. Account. 2003, 30, 573-588. [CrossRef]

26. Kim, C.-S.; Mauer, D.C.; Sherman, A.E. The Determinants of Corporate Liquidity: Theory and Evidence. J. Financ. Quant. Anal. 1998, 33, 335. [CrossRef]

27. Lazaridis, I.; Tryfonidis, D. Relationship between working capital management and profitability of listed companies on the Athens Stock Exchange. J. Financ. Manag. Anal. 2006, 19, 26-35.

28. Shin, H.H.; Soenen, L. Efficiency of working capital and corporate profitability. Financ. Practice Educ. 1998, $8,37-45$.

29. Ukaegbu, B. The significance of working capital management in determining firm profitability: Evidence from developing economies in Africa. Res. Int. Bus. Financ. 2014, 31, 1-16. [CrossRef]

30. Pompe, P.P.; Bilderbeek, J. The prediction of bankruptcy of small- and medium-sized industrial firms. J. Bus. Ventur. 2005, 20, 847-868. [CrossRef]

31. Hosaka, T. Bankruptcy prediction using imaged financial ratios and convolutional neural networks. Expert Syst. Appl. 2019, 117, 287-299. [CrossRef]

32. Enqvist, J.; Graham, M.; Nikkinen, J. The impact of working capital management on firm profitability in different business cycles: Evidence from Finland. Res. Int. Bus. Financ. 2014, 32, 36-49. [CrossRef]

33. Tinoco, M.H.; Wilson, N. Financial distress and bankruptcy prediction among listed companies using accounting, market and macroeconomic variables. Int. Rev. Financ. Anal. 2013, 30, 394-419. [CrossRef]

34. Antunes, F.; Ribeiro, B.; Pereira, F.C. Probabilistic modeling and visualization for bankruptcy prediction. Appl. Soft Comput. 2017, 60, 831-843. [CrossRef]

35. Zimon, G.; Sobolewski, M.; Lew, G. An Influence of Group Purchasing Organizations on Financial Security of SMEs Operating in the Renewable Energy Sector-Case for Poland. Energies 2020, 13, 2926. [CrossRef]

36. Marvel, H.P.; Yang, H. Group purchasing, nonlinear tariffs, and oligopoly. Int. J. Ind. Organ. 2008, 26, 1090-1105. [CrossRef]

37. Chen, Y.Y.; Kenneth, C.H.; Chao, D.; Shengli, L. To join or not to join group purchasing organisation: A vendor's decision. Eur. J. Operation. Res. 2017, 258, 581-589.

38. Sandberg, E.; Mena, C. Exploring strategic strengths and weaknesses of retail purchasing groups. Int. Rev. Retail. Distrib. Consum. Res. 2014, 25, 276-297. [CrossRef]

39. Yan, Y.; Zhao, R.; Lan, Y. Asymmetric retailers with different moving sequences: Group buying vs. individual purchasing. Eur. J. Oper. Res. 2017, 261, 903-917. [CrossRef] 
40. Burns, L.; Lee, J. Hospital purchasing alliances: Utilization, services and performance. Health Care Manag. Rev. 2008, 33, 203-215. [CrossRef]

41. Schotanus, F. Cooperative purchasing within the United Nations. In Proceedings of the IPSERA Conference, Archamps, France, 20-23 March 2005; pp. 961-973.

42. Nollet, J.; Beaulieu, M. The development of group purchasing: An empirical study in the healthcare sector. J. Purch. Supply Manag. 2003, 9, 3-10. [CrossRef]

43. Nollet, J.; Beaulieu, M. Should an organisation join a purchasing group? Supply Chain Manag. Int. J. 2005, 10, 11-17. [CrossRef]

44. Hu, Q.; Schwarz, L.B. Controversial Role of GPOs in Healthcare-Product Supply Chains. Prod. Oper. Manag. 2011, 20, 1-15. [CrossRef]

45. Schotanus, F.; Bakker, E.; Walker, H.; Lewis, M.A. Development of Purchasing Groups during Their Life Cycle: From Infancy to Maturity. Public Adm. Rev. 2011, 71, 265-275. [CrossRef]

46. Zimon, G. Influence of group purchasing organizations on financial situation of Polish SMEs. Oeconomia Copernic. 2018, 9, 87-104. [CrossRef]

47. Zhang, R.; Liu, B. Group buying decisions of competing retailers with emergency procurement. Ann. Oper. Res. 2016, 257, 317-333. [CrossRef]

48. Schotanus, F.; Telgen, J. Developing a typology of organisational forms of cooperative purchasing. J. Purch. Supply Manag. 2007, 13, 53-68. [CrossRef]

49. Walker, H.; Bakker, E.; Schotanus, F.; Harland, C. Choosing an organisational form: The case of collaborative procurement initiatives. Int. J. Procure. Manag. 2008, 1. [CrossRef]

50. Saha, R.L.; Seidmann, A.; Tilson, V. The Impact of Custom Contracting and the Infomediary Role of Healthcare GPOs. Prod. Oper. Manag. 2018, 28, 650-667. [CrossRef]

51. Safaei, A.S.; Heidarpoor, F.; Paydar, M.M. A novel mathematical model for group purchasing in healthcare. Oper. Res. Health Care 2017, 15, 82-90. [CrossRef]

52. Nollet, J.; Beaulieu, M.; Fabbe-Costes, N. The impact of performance measurement on purchasing group dynamics: The Canadian experience. J. Purch. Supply Manag. 2017, 23, 17-27. [CrossRef]

53. Schotanus, F.; Telgen, J.; De Boer, L. Critical success factors for managing purchasing groups. J. Purch. Supply Manag. 2010, 16, 51-60. [CrossRef]

54. Jain, N. Monitoring costs and trade credit. Q. Rev. Econ. Financ. 2001, 41, 89-110. [CrossRef]

55. Dana, M.J. Buyer groups as strategic commitments. Games Econ. Behav. 2012, 74, 470-485. [CrossRef]

56. Blair, R.D.; Durrance, C.P. Group Purchasing Organizations, Monopsony, and Antitrust Policy. Manag. Decis. Econ. 2013, 35, 433-443. [CrossRef]

57. Rozemeijer, F. How to manage corporate purchasing synergy in a decentralised company? Towards design rules for managing and organising purchasing synergy in decentralised companies. Eur. J. Purch. Supply Manag. 2000, 6, 5-12. [CrossRef]

58. Chipty, T.; Snyder, C.M. The Role of Firm Size in Bilateral Bargaining: A Study of the Cable Television Industry. Rev. Econ. Stat. 1999, 81, 326-340. [CrossRef]

59. Inderst, R.; Wey, C. Buyer power and supplier incentives. Eur. Econ. Rev. 2007, 51, 647-667. [CrossRef]

60. Snyder, C.M. A Dynamic Theory of Countervailing Power. RAND J. Econ. 1996, 27. [CrossRef]

61. Fonseca, L.M.; Domingues, J.P. The best of both worlds? Use of Kaizen and other continuous improvement methodologies within Portuguese ISO 9001 certified organizations. TQM J. 2018, 30, 321-334. [CrossRef]

62. Zimon, D. Impact of the implementation of quality management system on operating cost for small and medium-sized business organizations affiliated to a purchasing group. Int. J. Qual. Res. 2015, 9, 551-564.

63. Zimon, D.; Madzík, P. Standardized management systems and risk management in the supply chain. Int. J. Qual. Reliab. Manag. 2019, 37, 305-327. [CrossRef]

64. Suhardi, A.R.; Rozak, A. Supply chain management and total quality management in textile manufacturing companies. J. Adv. Res. Dyn. Control Syst. 2019, 11, 173-177.

65. Bastas, A.; Liyanage, K. Sustainable supply chain quality management: A systematic review. J. Clean. Prod. 2018, 181, 726-744. [CrossRef] 
66. Petronijević, V.; Đorđević, A.; Stefanović, M.; Arsovski, S.; Krivokapić, Z.; Mišić, M. Energy Recovery through End-of-Life Vehicles Recycling in Developing Countries. Sustain. 2020, 12, 8764. [CrossRef]

Publisher's Note: MDPI stays neutral with regard to jurisdictional claims in published maps and institutional affiliations.

(C) 2020 by the authors. Licensee MDPI, Basel, Switzerland. This article is an open access article distributed under the terms and conditions of the Creative Commons Attribution (CC BY) license (http://creativecommons.org/licenses/by/4.0/). 